\title{
Reconstruction of Social and Environmental Responsibility Policies for Companies in Central Java
}

\author{
Monica Puspa Dewi Suganda Putri ${ }^{1}$, Adji Samekto ${ }^{2}$, Yusriyadi ${ }^{3}$ and RB. Sularto ${ }^{4}$ \\ \{monica.puspa@yahoo.com ${ }^{1}$, samektoadjifx@gmail.com ${ }^{2}$, prof.yusriyadi@gmail.com ${ }^{3}$, \\ sulartob@gmail.com $\left.{ }^{4}\right\}$ \\ 1,2,3,4 Diponegoro University, J1.Prof. H. Soedarto, S.H. Tembalang, Tembalang, Kota Semarang, Jawa \\ Tengah, 50275, Indonesia
}

\begin{abstract}
The development of Corporate Social and Environmental Responsibility (TJSLP) is now followed by the strengthening of the existence of TJSLP into normative obligations in various countries, including Indonesia. From the philosophical aspect, the TJSLP in Indonesia has been embedded in the soul of Pancasila and the 1945 Constitution. The state shall protect all citizens, realize general prosperity, educate the life of the nation, and participate in implementing the world order. The national economy and social welfare must be regulated by the state as much as possible for the welfare of the people. Various laws and regulations reinforce it, i.e., Article 74 of Law no. 40 of 2007 on Limited Liability Company, Article 15 of Law no. 25 of 2007 on Investment, the Regional Government (PP) No.. 47 of 2012 on Corporate Social and Environmental Responsibility for Limited Liability Company, Article 17-18 of the Regional Regulation of Central Java Province no. 7 of 2010, Article 3 of Law no. 11 of 2009 on Social Welfare, Article 2 of Law No. of 2009 on StateOwned Company, Article 14 of Law no. 32 of 2009 on Environment, and Article 36 of Law no. 13 of 2011 on the Handling of Poor. Meanwhile, in terms of the empirical practice, it shows that there is no legislation that regulates the TJSLP in Central Java and the TJSLP that have been implemented by some companies in Central Java whether they have been in accordance with the RPJMD of Central Java or not, namely the purpose, direction, development strategy of Central Java. As a potential, the TJSLP should be juxtaposed with regional government programs related to social and environmental programs. The paradigm used is Constructivism. The method used was socio-legal, and the researcher conducted empirical research with a qualitative approach.
\end{abstract}

Keywords: Corporate Social Responsibility, Environmental Responsibility, Corporate Law, Central Java

\section{Introduction}

In general, the management of Natural Resources (SDA) in Indonesia, until recently, is based on the efforts to meet investment needs in the framework of economic recovery. The policy describes that the management of natural resources is viewed and understood in the context of economic sense and has not led to an ecological and sustainable sense. Natural resource management practices do not pay attention to the aspects of vulnerability and the limited carrying capacity of natural resources, the welfare of local communities, workers, and environmental degradation. However, in line with the enactment of various regulations on Corporate Social and Environmental Responsibility (TJSLP), corporate is no longer a selfish entity, an alienation and/ or exclusivity of the community, but it is a legal entity (Recht 
person) that must adapt the socio-culture to the environment where it is located and is held accountable like general legal subjects[1]. The TJSL which has been carried out in the sense of voluntary, in the future, must be mandatory. The basis of the view is inseparable from Article 33 Paragraph (4) of the 1945 Constitution, which affirms "the national economy is organized based on economic democracy with the principles of togetherness, fair efficiency, sustainability, environmental insight, independence, and by maintaining the balance of national economic progress and unity."

Theoretically, the TJSL is the core of business ethics in which a company does not only have economic and legal obligations to shareholders, but it also has obligations to other stakeholders. They are all inseparable from the fact that a company cannot live, operate, and survive and gain profits without the help of various parties[2].

Corporate's concern is seen from the corporate's commitment to account for all impacts of its business activities in the dimensions of the economic, social, and environment (Triple Bottom Line). For a company that is consistent in applying the TJSL in its activities, in the long term, it will gain profit in the form of trust from its stakeholders (corporate image) to the company concerned. Therefore, this condition has become a serious concern from business circles both nationally and internationally. The facts indicate a positive correlation between the companies that run the TJSL in their business activities and public appreciation. Therefore, the TJSL is no longer considered a "cost" but a long-term investment for the company concerned.

\section{Method}

The paradigm used in this research was the paradigm of Constructivism of Guba and Lincoln. The method used was a qualitative method using a socio-legal approach. The theory used was Notonagoro's theory of justice.

In the concept of Notonagoro[3], the relation of Pancasila precepts is a relationship of conformity. The essential meaning of each of the precepts of Pancasila is: The principle of the One Supreme God means that the appropriateness of the attributes and circumstances of and within the state with the essence of God is the first cause of all things or causa prima that exists forever or ever. There is only one, which is the origin and purpose of all things. In this paper, the nature of Pancasila will not be discussed in detail, but it goes towards the concept of Justice initiated by Notonagoro.

Notonagoro defines justice as the ability to give to oneself and others what is right and what has become their rights[4]. Justice arises as a consequence when humans must execute relations and cooperation with others to realize his goal. In every life with a human being with an organization as a container of its people's unity, there is a relationship of justice. Its relation with the TJSLP is that the relationship of justice is reflected in the relations of the State, companies, and citizen which is a continuity relationship; a relationship that must exist and all three functions as an instrument for sharing and distributing justice (the creation of a balance between rights and obligations).

\section{Findings}

In this case, the writers wanted to present that, from the results of the research conducted by the writers, it was found that the TJSL budget should be taken from the allocation of corporate profits. However, in reality, especially in the oil companies primarily engaged in exploration (which have not gained profits yet), the TJSL funds are budgeted from a particular 
post through the General Meeting of Shareholders and included in the company's annual budget.

The research results show that, in some oil and gas companies operating in Central Java, such as PT. Blora Patra Gas Hulu, PT Pertamina Asset 4, and PT. Pertamina EP Geo Cepu Indonesia, the characteristics of the TJSL are still philanthropy or generosity. A TJSL Forum that brings together all stakeholders at the same time and place to discuss, to think together, and to unify vision and mission in allocating the TJSL funds has not been established. The development is adapted to the medium or long term development direction/ plan of the region for the realization of the improvement of people's welfare with its social justice. In East Java, a CSR Forum has been formed in which all stakeholders, both businesses and corporations which are not limited to the oil and gas sector only, together with community leaders and government organizers, synergize to contribute the best for the equity and improvement of people's welfare in East Java.

Justice, as a value, develops along with the development of human civilization. It means that the development of human thought strongly influences the understanding of justice value as an entity that requires the value itself. There is a close relationship between value and perspective of life. The value of life is based on the beliefs in which the firmly held values will become the basis, direction, and purpose of life[5]. The subjective nature of value provides an opportunity for Indonesia to formulate its moral values by Indonesian personality traits.

Meanwhile, the objective nature of value gives signs that in exploring and formulating subjective values, it is necessary to consider the objectivity and universality of values that can be generally understood and recognized. When the values fall into the category of moral values, there are consequences to be applied in action. Given its subjective and objective nature, realizing value as a moral norm requires a struggle followed by both theoretical and empirical arguments so that the value can be accounted for, acknowledged, and practiced in daily life.

Capitalism defines justice by placing individuals as goal orientation. Achievers are entitled to their rights. Conversely, a person with no achievement is not entitled to any reward. People who are unable to work are not entitled to eat[6]. The state must ensure that every individual has an opportunity to actualize himself and to protect property rights for his labor. The consequences of the size of the moral value used; if the state or the existence of actions cause disruptions to the individual to actualize himself maximally and limit the concerned to obtain his rights following the achievements achieved, the action is immoral.

Pancasila as the way of life and the state's foundation of the Republic of Indonesia is Pancasila with its precepts listed in the preamble to the fourth paragraph of the 1945 Constitution. Materially, the precepts of Pancasila are rooted in the values and culture of the Indonesian nation, both the ones practiced and becoming the ideals.

\section{Conclusion}

Meanwhile, in terms of empirical practice, there is no legal basis that regulates the TJSLP in Central Java, and the TJSLP which had been conducted by some companies in Central Java has not been by the RPJMD of Central Java, namely the purpose, direction, and development strategy of Central Java. The TJSLP that is rolled out is incidental, sectoral, and philanthropy, not sustainable empowerment.

It is expected that, through this research, a strategic and directive policy can be formed to accommodate both current and future conditions, especially on Corporate Social and Environmental Responsibility in realizing social justice and welfare equity. 


\section{References}

[1] A. Vives, "Social and Environment Responsibility in Small And Medium Enterprises in Latin America," J. Corp. Citizsh., vol. 21, pp. 39-50, 2006.

[2] M. Kaptein, "The Battle for Business Ethics: A Struggle Theory," J. Bus. Ethics, vol. 4, no. 2, 2017.

[3] Z. . [et. al. Salampessy, "Pancasila Paradigm: Methodology of Wawasan Nusantara of Accounting of Pancasila," Aust. Account. Bussiness Financ. J., vol. 1, 2 AD.

[4] R.; A. H. and M. A. S. Marbun, "Legal Philosophy of Pancasila as The Paradigm of The Criminal Justice System: Philosophical Criticism For The Lost of A Sense of Humanity," in SHS Web. Conference, 2018.

[5] H. Dagan, The Value of Choice and The Justice Contract, Jurisprudence. 2019.

[6] J. R. Commons, Legal Foundation of Capitalism 1st Edition. New York: Routledge, 2017. 